\title{
Comparison of the Clinical Efficacy of Four Different Liposomal Sprays for the Treatment of Dry Eye
}

\author{
Andreas Hueck ${ }^{1 *}$, Reinhard Wehrmann ${ }^{2}$ \\ ${ }^{1}$ Private Ophthalmology Practice, Holzkirchen, Germany \\ ${ }^{2}$ Private Ophthalmology Practice, Miesbach, Germany \\ Email: ^andreas.hueck@gmx.de
}

How to cite this paper: Hueck, A. and Wehrmann, R. (2017) Comparison of the Clinical Efficacy of Four Different Liposomal Sprays for the Treatment of Dry Eye. Open Journal of Ophthalmology, 7, 103116.

https://doi.org/10.4236/ojoph.2017.72015

Received: March 14, 2017

Accepted: May 15, 2017

Published: May 18, 2017

Copyright $\odot 2017$ by authors and Scientific Research Publishing Inc. This work is licensed under the Creative Commons Attribution International License (CC BY 4.0).

http://creativecommons.org/licenses/by/4.0/

\begin{abstract}
Purpose: To compare the clinical efficacy of four different liposomal sprays for dry eye treatment. Methods. Prospective randomized consecutive intraindividual comparison enrolling 166 patients (age, 18 - 93 years). Patients were randomly assigned to one of 4 groups, receiving one spray in their right eye and another one in their left eye: Ocuvers Hyaluron $(\mathrm{OH})$ (87 eyes) and Ocuvers Lipostamin (OL) (80 eyes) (Innomedis AG), and Tears Again (TA) (80 eyes) and Tears Again Sensitive (TAS) (85 eyes) (Optima Pharmaceutical). Symptomatology was evaluated with the OSDI (Ocular Surface Disease Index) questionnaire. Subjective comfort, tear break up time (TBUT), redness, tear meniscus, application comfort and smell were evaluated during a 30-minute follow-up. Results. Smell for TA and TAS was significantly fattier compared to $\mathrm{OH}$ and $\mathrm{OL}(\mathrm{p}<0.001)$. After application of TA, patients reported significantly more burning sensations compared to the rest of the sprays $(\mathrm{p}<0.001)$. At 10 minutes, subjective comfort $(\mathrm{p} \leq 0.027)$ and TBUT $(\mathrm{p} \leq 0.004)$ were significantly better with $\mathrm{OH}$ and OL compared to TA and TAS. At 30 minutes, the same trends were observed, with also significantly less ocular redness with OL compared to the rest $(\mathrm{p}=0.043)$. Significant correlations were found between baseline OSDI and changes in ocular redness at $10(\mathrm{r}=-0.287, \mathrm{p}=$ $0.011)$ and 30 minutes $(r=-0.237, p=0.037)$ after the application of OL. Conclusions. The four evaluated liposome sprays may be useful for dry eye treatment, with higher subjective comfort and less dry eye signs using the Ocuvers sprays. The use of OL may be a better treatment option for severe dry eye.
\end{abstract}

\section{Keywords}

Liposomal Spray, Dry Eye, Ocuvers, Tears Again, Tear Break Up Time, Redness, Smell 


\section{Introduction}

Dry eye syndrome (DES) is an ocular condition characterized, according to the Definition and Classification Subcommittee of the International Dry Eye Workshop (2007), by the presence of symptoms, ocular surface lesions, tear instability and tear hyperosmolarity [1]. It has a variable prevalence that ranges from $0.39 \%$ to $30 \%$ in patients older than 50 years [2] [3] [4] [5]. Age and gender have been defined as two of the most relevant risk factors for DES [4]. Several options of treatment have been developed and tested for this ocular condition, such as artificial tears, lipid-containing lubricants, inserts, anti-inflammatory or immunosuppressant drops, antibiotics, dietary omega-3 essential fatty acids, autologous serum, intense-pulsed-light (IPL), punctual plugs, moisture-retaining eyeglasses, hydrophilic bandage contact lenses or secretagogues [6]. Liposomal sprays are another option for treatment of DES [7]. These sprays contain phospholipid liposomes to overcome the disturbance of the lipid phase which is present in around $80 \%$ of patients with DES [7]. Several studies have confirmed the efficacy of this type of sprays, with significant improvements in eyelid edge parallel conjunctival folds (LIPCOF), tear break-up time (TBUT), Schirmer I test outcome, and symptoms [7]-[12]. Different liposomal spray formulations have been developed and commercially released. However, only one study has compared the clinical effect of some of them [10]. Specifically, Pult et al. [10] demonstrated that OptrexActiMist (AM, Optima-Pharma, Germany) (same formulation as Tears Again) was significantly better in terms of ocular comfort and tear film stability improvement than TearMist and DryEyesMist sprays. The aim of the current study was to compare the clinical effect of four different liposomal sprays for DES treatment in terms of subjective comfort, ocular redness, and TBUT as well as in terms of application comfort and smell in a sample of patients with different levels of dry eye symptomatology.

\section{Patients and Methods}

\subsection{Patients}

Patients with a diagnosis of dry eye were randomized to one of the following four groups: Ocuvers Hyaluron (OH) (Innomedis AG, Germany) vs. Tears Again (TA) (Optima Pharmaceutical GmbH, Germany), $\mathrm{OH}$ vs. Tears Again Sensitive (TAS) (Optima Pharmaceutical GmbH, Germany), Ocuvers Lipostamin (OL) (Innomedis AG, Germany) vs. TA and OL vs. TAS. Patients were randomly assigned to the spray they receive in the right eye which was defined to be the first eye to be treated. The various labels of the four sprays are listed in Table 1.

Symptomatology was evaluated with the OSDI (Ocular Surface Disease Index) questionnaire which is a valid and reliable instrument for measuring the severity of dry eye disease, and possesses the necessary psychometric properties to be used in clinical research [13]. It consists of 12 questions about common symptoms in the dry eye disease and a scoring system for obtaining an overall index for being used as an indicator of the severity of the disease [13]. Included in the 
Table 1. Different labels of the four tear spray products used in the study.

\begin{tabular}{cc}
\hline Original Product & Available Other Labels \\
\hline Ocuvers spay hyaluron & Okuzell Lipidspray \\
Ocuvers spray lipostamin & - \\
Tears Again & LipoNit \\
& Polyeye Comfort \\
& Optrex Actispray 2 in 1 for dry eyes \\
Tears Again Sensitive & LipoNit Sensitive \\
& Optrex Actisrpay 2 in 1 for tired eyes \\
& Omnimed Lidspray \\
& Omnitears Lidspray
\end{tabular}

study were subjects with different level of dry eye symptoms (OSDI grades 1, 2, 3 or 4) and a signed informed consent. Exclusion criteria included the use of an artificial tear or other eye drop on the day of examination, any degenerative ocular pathology and ocular inflammation. The study received Ethics Committee approval and was carried out in accordance with the tenets of the Declaration of Helsinki.

\subsection{Examination Protocol}

An OSDI assessment was performed in all patients. The following subjective parameters were evaluated: subjective comfort, using a scale from 0 (very bad) to 100 (excellent), application comfort, using a scale from 0 (not burning at all) to 100 (strongly burning), and smell (scale from 0 - no smell to 5-extremely fatty smell). The following objective parameters were measured with keratography (Oculus Keratograph 5M, Oculus GmbH, Wetzlar, Germany): non-invasive tear break up time (TBUT), including the first measure of three consecutive measurements and the average, general conjunctival redness using a scale from 1 (slight) to 3 (strong) as well as the mean value of bulbar and nasal redness, and tear meniscus (evaluated as mild, normal, moderate and severe). The variables were assessed before (subjective comfort, TBUT, tear meniscus, redness) and/or during (subjective comfort, application comfort, smell) the application of the spray as well as 10 and 30 minutes after its application.

\subsection{Liposome Sprays}

$\mathrm{OH}$ spray is composed of a phospholipid complex, sodium-hyaluronate, and an isotonic borate-buffered solution ( $\mathrm{pH}$ : 7.2). OL spray has the same composition except sodium-hyaluronate which is replaced by several natural plant extracts: capparis spinose, helychrysum italicum, euphrasia officinalis, and glyccyrrhiza glabra. TA spray is composed of the following elements: 2-phenoxyethanol, phospholipid (from soy bean), retinol sodium chloride, alpha-tocopherol, and ethanol, whereas TAS has a modified composition including phospholipid (from soy bean), sodium chloride and ethanol, but also retinol palmitate, dexpanthenol, and DL-alpha-tocopherol. 


\subsection{Statistical Analysis}

Sample size was calculated with $G^{*}$ Power 3.1.9.2. For the primary endpoint, a TBUT difference of $4 \mathrm{sec}$ between pre-application and post-application of the spray was chosen. The standard deviation was expected to be $8 \mathrm{sec}$ at both application times. For an alpha of 0.05 and a power of 0.95 a sample size of 47 eyes per comparison has been calculated.

Statistical analyses were performed with a commercially available software package (SPSS for Mac, Version 20.0; IBM Corporation, Armonk, NY, USA). Normality of data samples was evaluated by means of the Kolmogorov-Smirnov test. When parametric analysis was possible, the 1-way analysis of variance (ANOVA) with Bonferroni post-hoc analysis was used for comparisons between spray groups, whereas the Kruskal-Wallis test was applied to assess the significance of such differences when parametric analysis was not possible. The Mann-Whitney test with the Bonferroni's adjustment was used for the post-hoc analysis of the Kruskal-Wallis test outcome. For all statistical tests, a p-value of less than 0.05 was considered as statistically significant.

\section{Results}

A total of 332 eyes from 166 patients with an age range from 18 to 93 years was included in the study (mean age: 64.3 years). The sample included 87 eyes (26.2\%) using $\mathrm{OH}, 80$ eyes (24.1\%) using TA, 85 eyes (25.6\%) using TAS, and 80 eyes (24.1\%) using OL. Table 2 shows a comparative analysis of the clinical data obtained before/during the application of the spray in each group. As shown, statistically significant differences were found between groups in spray application comfort and smell $(\mathrm{p}<0.001)$ which were both measured during application. Specifically, the smell of TA and TAS was significantly fattier than the smell of $\mathrm{OH}$ and $\mathrm{OL}(\mathrm{p}<0.001)$. Whereas patients rated the smell of $\mathrm{OH}$ and OL between "no smell" and "hardly perceivable smell" the rating of TA and TAS was in average between "moderate" and "very intense fatty smell". Likewise, comfort immediately after application was significantly better (less burning) using $\mathrm{OH}$ compared to TA $(\mathrm{p}<0.01)$ and TAS $(\mathrm{p}=0.026)$, and using OL compared to TA $(\mathrm{p}<0.001)$.

Ten minutes after the application of the spray, there were statistically significant differences between spray groups in subjective comfort, TBUT, spray application comfort and smell ( $\mathrm{p}<0.001)$ (Table 3 and Figure 1). Specifically, subjective comfort was significantly better and TBUT significantly higher with $\mathrm{OH}$ and OL compared to TA and TAS ( $\mathrm{p} \leq 0.027)$. Likewise, smell was reported to be significantly less fatty for OH and OL compared to TA and TAS ( $p<0.001$ ) and application comfort was significantly better with $\mathrm{OH}$ and OL compared to TA $(\mathrm{p}<0.001)$ (Table 3 and Figure 1$)$. Thirty minutes after the application of the spray, statistically significant differences were found between spray groups in all clinical variables evaluated ( $\mathrm{p} \leq 0.047$ ) (Table 4 and Figure 1), with similar results than those found at 10 minutes after application. No significant differences were found in the distribution of tear meniscus outcomes before the 
Table 2. Clinical data obtained before/during application of the spray. Abbreviations: TBUT, tear break up time; OH, Ocuvers Hyaluron; TA, Tears Again; TAS, Tears Again Sensitive; OL, Ocuvers Lipostamin.

\begin{tabular}{|c|c|c|c|c|c|}
\hline $\begin{array}{c}\text { Mean (SD) } \\
\text { Median (Range) }\end{array}$ & $\mathrm{OH}$ & OL & TA & TAS & $\mathrm{p}$-value \\
\hline $\begin{array}{c}\text { Age } \\
\text { (years) }\end{array}$ & $\begin{array}{c}65.7(16.9) \\
69.0(19 \text { to } 93)\end{array}$ & $\begin{array}{c}63.1(17.5) \\
68.0(18 \text { to } 93)\end{array}$ & $\begin{array}{c}64.5(18.1) \\
69.5(19 \text { to } 93)\end{array}$ & $\begin{array}{c}64.0(16.3) \\
69.0(18 \text { to } 90)\end{array}$ & 0.754 \\
\hline OSDI & $\begin{array}{c}16.7(16.2) \\
13.0(0 \text { to } 63)\end{array}$ & $\begin{array}{c}14.7(16.7) \\
8.0(0 \text { to } 73)\end{array}$ & $\begin{array}{c}17.5(17.8) \\
12.5(0 \text { to } 73)\end{array}$ & $\begin{array}{c}14.0(15.1) \\
8.0(0 \text { to } 69)\end{array}$ & 0.412 \\
\hline Subjective comfort & $\begin{array}{c}63.4(21.8) \\
60.0(20 \text { to } 100)\end{array}$ & $\begin{array}{c}69.8(24.9) \\
70.0(0 \text { to } 100)\end{array}$ & $\begin{array}{c}66.2(23.5) \\
70.0(0 \text { to } 100)\end{array}$ & $\begin{array}{c}68.0(23.5) \\
70.0(20 \text { to } 100)\end{array}$ & 0.200 \\
\hline Ocular redness & $\begin{array}{c}0.4(0.6) \\
0.0(0 \text { to } 2)\end{array}$ & $\begin{array}{c}0.3(0.5) \\
0.0(0 \text { to } 1)\end{array}$ & $\begin{array}{c}0.4(0.5) \\
0.0(0 \text { to } 2)\end{array}$ & $\begin{array}{c}0.3(0.5) \\
0.0(0 \text { to } 1)\end{array}$ & 0.860 \\
\hline $\begin{array}{l}\text { Bulbar and nasal conjunctival } \\
\text { redness }\end{array}$ & $\begin{array}{c}1.3(0.6) \\
1.2(0.0 \text { to } 2.5)\end{array}$ & $\begin{array}{c}1.2(0.5) \\
1.2(0.2 \text { to } 2.2)\end{array}$ & $\begin{array}{c}1.2(0.6) \\
1.1(0.0 \text { to } 2.5)\end{array}$ & $\begin{array}{c}1.2(0.5) \\
1.2(0.0 \text { to } 2.4)\end{array}$ & 0.781 \\
\hline $\begin{array}{c}\text { TBUT } 1^{\text {st }} \text { measurement } \\
\text { (seconds) }\end{array}$ & $\begin{array}{c}7.6(5.8) \\
5.5(1.2 \text { to } 25.0)\end{array}$ & $\begin{array}{c}6.4(5.3) \\
4.6(0.8 \text { to } 25.0)\end{array}$ & $\begin{array}{c}7.3(5.7) \\
5.0(1.2 \text { to } 24.0)\end{array}$ & $\begin{array}{c}6.7(5.7) \\
4.6(1.2 \text { to } 25.0)\end{array}$ & 0.413 \\
\hline $\begin{array}{l}\text { TBUT average } \\
\text { (seconds) }\end{array}$ & $\begin{array}{c}10.4(5.7) \\
9.6(2.2 \text { to } 25.0)\end{array}$ & $\begin{array}{c}8.7(5.3) \\
7.3(1.9 \text { to } 25.0)\end{array}$ & $\begin{array}{c}10.4(6.2) \\
8.4(2.3 \text { to } 24.0)\end{array}$ & $\begin{array}{c}10.0(5.9) \\
8.3(1.3 \text { to } 25.0)\end{array}$ & 0.156 \\
\hline Smell & $\begin{array}{c}0.3(0.6) \\
0.0(0 \text { to } 3)\end{array}$ & $\begin{array}{c}0.5(0.8) \\
0.0(0 \text { to } 3)\end{array}$ & $\begin{array}{c}3.3(1.7) \\
4.0(0 \text { to } 5)\end{array}$ & $\begin{array}{c}2.9(1.5) \\
3.0(0 \text { to } 5)\end{array}$ & $\begin{array}{c}<0.001 \\
\text { OH-TA }<0.001 \\
\text { OH-TAS }<0.001 \\
\text { OL-TA }<0.001 \\
\text { OL-TAS }<0.001\end{array}$ \\
\hline Application comfort & $\begin{array}{c}0.1(1.1) \\
0.0(0 \text { to } 10)\end{array}$ & $\begin{array}{c}0.5(2.7) \\
0.0(0 \text { to } 20)\end{array}$ & $\begin{array}{c}13.6(20.7) \\
0.0(0 \text { to } 80)\end{array}$ & $\begin{array}{c}2.0(7.4) \\
0.0(0 \text { to } 40)\end{array}$ & $\begin{array}{c}<0.001 \\
\text { OH-TA }<0.001 \\
\text { OH-TAS } 0.026 \\
\text { OL-TA }<0.001 \\
\text { OL-TAS } 0.210\end{array}$ \\
\hline
\end{tabular}

application of the liposomal sprays $(\mathrm{p}=0.065)$ and at 10 minutes after the application of the spray $(\mathrm{p}=0.138)$ (Figure 2$)$. However, a significantly higher proportion of eyes with high tear meniscus was observed at 30 minutes after the application of the spray in the OH and OL groups $(\mathrm{p}=0.037)$ (Figure 2$)$.

When changes in ocular comfort at 10 and 30 minutes after spray application were compared in the four spray groups, statistically significant differences were found between groups in the change in ocular comfort, conjunctival redness, and TBUT $(\mathrm{p}<0.001)$. All these parameters improved significantly more with $\mathrm{OH}$ and OL compared to TA or TAS ( $\mathrm{p} \leq 0.031)$, except for one comparison (difference in change of ocular redness $(p=0.095)$ and first measurement of TBUT ( $p=0.137$ ) between OH and TAS at 10 minutes) (Table 5).

Finally, Table 6 summarizes the correlation between the changes in subjective comfort, redness and TBUT (10 and 30 minutes after application) and the baseline OSDI value. Statistically significant positive correlations between baseline OSDI 
Table 3. Clinical data obtained 10 minutes after application of the spray. Abbreviations: TBUT, tear break up time; OH, Ocuvers Hyaluron; TA, Tears Again; TAS, Tears Again Sensitive; OL, Ocuvers Lipostamin.

\begin{tabular}{|c|c|c|c|c|c|}
\hline $\begin{array}{c}\text { Mean (SD) } \\
\text { Median (Range) }\end{array}$ & $\mathrm{OH}$ & OL & TA & TAS & p-value \\
\hline Subjective comfort & $\begin{array}{c}80.7(17.2) \\
80.0(20 \text { to } 100)\end{array}$ & $\begin{array}{c}86.0(16.0) \\
90.0(20 \text { to } 100)\end{array}$ & $\begin{array}{c}59.4(22.9) \\
60.0(5 \text { to } 100)\end{array}$ & $\begin{array}{c}73.5(21.6) \\
70.0(20 \text { to } 100)\end{array}$ & $\begin{array}{c}<0.001 \\
\text { OH-TA }<0.001 \\
\text { OH-TAS } 0.027 \\
\text { OL-TA }<0.001 \\
\text { OL-TAS }<0.001\end{array}$ \\
\hline Ocular redness & $\begin{array}{c}0.4(0.5) \\
0.0(0 \text { to } 1)\end{array}$ & $\begin{array}{c}0.3(0.5) \\
0.0(0 \text { to } 1)\end{array}$ & $\begin{array}{c}0.4(0.5) \\
0.0(0 \text { to } 2)\end{array}$ & $\begin{array}{c}0.3(0.5) \\
0.0(0 \text { to } 1)\end{array}$ & 0.354 \\
\hline $\begin{array}{c}\text { Bulbar and nasal conjunctival } \\
\text { redness }\end{array}$ & $\begin{array}{c}1.2(0.5) \\
1.1(0.0 \text { to } 2.2)\end{array}$ & $\begin{array}{c}1.2(0.5) \\
1.1(0.2 \text { to } 2.2)\end{array}$ & $\begin{array}{c}1.3(0.6) \\
1.3(0.0 \text { to } 2.5)\end{array}$ & $\begin{array}{c}1.3(0.5) \\
1.2(0.3 \text { to } 2.3)\end{array}$ & 0.267 \\
\hline $\begin{array}{l}\text { TBUT } 1^{\text {st }} \text { measurement } \\
\text { (seconds) }\end{array}$ & $\begin{array}{c}9.5(6.6) \\
8.2(1.7 \text { to } 25.0)\end{array}$ & $\begin{array}{c}8.9(5.5) \\
8.4(1.2 \text { to } 24.0)\end{array}$ & $\begin{array}{c}6.3(5.2) \\
4.5(0.8 \text { to } 24.0)\end{array}$ & $\begin{array}{c}7.1(5.8) \\
4.8(1.2 \text { to } 25.0)\end{array}$ & $\begin{array}{c}\quad<0.001 \\
\text { OH-TA }<0.001 \\
\text { OH-TAS } 0.004 \\
\text { OL-TA }<0.001 \\
\text { OL-TAS } 0.002\end{array}$ \\
\hline $\begin{array}{l}\text { TBUT average } \\
\text { (seconds) }\end{array}$ & $\begin{array}{c}13.3(5.7) \\
12.2(2.5 \text { to } 25.0)\end{array}$ & $\begin{array}{c}12.3(5.2) \\
11.2(2.5 \text { to } 24.0)\end{array}$ & $\begin{array}{c}9.4(5.5) \\
8.6(2.0 \text { to } 24.0)\end{array}$ & $\begin{array}{c}10.2(5.9) \\
10.9(2.4 \text { to } 25.0)\end{array}$ & $\begin{array}{c}<0.001 \\
\text { OH-TA }<0.001 \\
\text { OH-TAS }<0.001 \\
\text { OL-TA }<0.001 \\
\text { OL-TAS } 0.002\end{array}$ \\
\hline Smell & $\begin{array}{c}0.1(0.4) \\
0.0(0 \text { to } 2)\end{array}$ & $\begin{array}{c}0.1(0.5) \\
0.0(0 \text { to } 2)\end{array}$ & $\begin{array}{c}2.6(1.6) \\
3.0(0 \text { to } 5)\end{array}$ & $\begin{array}{c}2.0(1.5) \\
2.0(0 \text { to } 5)\end{array}$ & $\begin{array}{c}<0.001 \\
\text { OH-TA }<0.001 \\
\text { OH-TAS }<0.001 \\
\text { OL-TA }<0.001 \\
\text { OL-TAS }<0.001\end{array}$ \\
\hline Application comfort & $\begin{array}{c}0.8(6.5) \\
0.0(0 \text { to } 60)\end{array}$ & $\begin{array}{c}0.6(5.6) \\
0.0(0 \text { to } 50)\end{array}$ & $\begin{array}{c}6.9(15.4) \\
0.0(0 \text { to } 60)\end{array}$ & $\begin{array}{c}0.8(3.5) \\
0.0(0 \text { to } 20)\end{array}$ & $\begin{array}{c}<0.001 \\
\text { OH-TA }<0.001 \\
\text { OH-TAS } 0.241 \\
\text { OL-TA }<0.001 \\
\text { OL-TAS } 0.119\end{array}$ \\
\hline
\end{tabular}

and ocular comfort changes after the application of the spray were found in all groups, although correlations were poor $(0.227 \leq \mathrm{r} \leq-0.356, \mathrm{p} \leq 0.037)$. Likewise, statistically significant negative correlations were found between baseline OSDI and the changes in ocular redness at 10 minutes $(r=-0.287, p=0.011)$ and 30 minutes $(r=-0.237, \mathrm{p}=0.037)$ after the application of the OL spray (Table 6).

\section{Discussion}

In the current study, an improvement in subjective comfort, meniscus evaluation and TBUT as well as some level of reduction in bulbar and nasal conjunctival redness were observed after the use of the four liposomal sprays evaluated. 
Table 4. Clinical data obtained 30 minutes after application of the spray. Abbreviations: TBUT, tear break up time; OH, Ocuvers Hyaluron; TA, Tears Again; TAS, Tears Again Sensitive; OL, Ocuvers Lipostamin.

\begin{tabular}{|c|c|c|c|c|c|}
\hline $\begin{array}{c}\text { Mean (SD) } \\
\text { Median (Range) }\end{array}$ & $\mathrm{OH}$ & OL & TA & TAS & p-value \\
\hline Subjective comfort & $\begin{array}{c}82.2(16.9) \\
80.0(20 \text { to } 100)\end{array}$ & $\begin{array}{c}86.9(16.3) \\
90.0(20 \text { to } 100)\end{array}$ & $\begin{array}{c}62.0(21.7) \\
60(20 \text { to } 100)\end{array}$ & $\begin{array}{c}73.4(22.4) \\
70.0(20 \text { to } 100)\end{array}$ & $\begin{array}{c}<0.001 \\
\text { OH-TA }<0.001 \\
\text { OH-TAS } 0.010 \\
\text { OL-TA }<0.001 \\
\text { OL-TAS }<0.001\end{array}$ \\
\hline Ocular redness & $\begin{array}{c}0.4(0.5) \\
0.0(0 \text { to } 1)\end{array}$ & $\begin{array}{c}0.2(0.4) \\
0.0(0 \text { to } 1)\end{array}$ & $\begin{array}{c}0.4(0.5) \\
0.0(0 \text { to } 2)\end{array}$ & $\begin{array}{c}0.4(0.5) \\
0.0(0 \text { to } 1)\end{array}$ & $\begin{array}{c}0.043 \\
\text { OH-TA } 0.214 \\
\text { OH-TAS } 0.784 \\
\text { OL-TA } 0.005 \\
\text { OL-TAS } 0.052\end{array}$ \\
\hline $\begin{array}{c}\text { Bulbar and nasal conjunctival } \\
\text { redness }\end{array}$ & $\begin{array}{c}1.1(0.5) \\
1.1(0.0 \text { to } 2.1)\end{array}$ & $\begin{array}{c}1.1(0.5) \\
1.1(0.2 \text { to } 2.1)\end{array}$ & $\begin{array}{c}1.3(0.6) \\
1.2(0.3 \text { to } 2.5)\end{array}$ & $\begin{array}{c}1.2(0.5) \\
1.2(0.3 \text { to } 2.2)\end{array}$ & $\begin{array}{c}0.047 \\
\text { OH-TA } 0.079 \\
\text { OH-TAS } 0.241 \\
\text { OL-TA } 0.012 \\
\text { OL-TAS } 0.045\end{array}$ \\
\hline $\begin{array}{c}\text { TBUT } 1^{\text {st }} \text { measurement } \\
\text { (seconds) }\end{array}$ & $\begin{array}{c}12.1(6.9) \\
9.5(2.2 \text { to } 25.0)\end{array}$ & $\begin{array}{c}11.4(6.9) \\
9.4(2.1 \text { to } 24.0)\end{array}$ & $\begin{array}{c}6.5(5.8) \\
4.4(2.0 \text { to } 25.0)\end{array}$ & $\begin{array}{c}7.2(5.7) \\
5.4(1.2 \text { to } 25.0)\end{array}$ & $\begin{array}{c}<0.001 \\
\text { OH-TA }<0.001 \\
\text { OH-TAS }<0.001 \\
\text { OL-TA }<0.001 \\
\text { OL-TAS }<0.001\end{array}$ \\
\hline $\begin{array}{l}\text { TBUT average } \\
\text { (seconds) }\end{array}$ & $\begin{array}{c}15.0(5.7) \\
14.1(2.7 \text { to } 25.0)\end{array}$ & $\begin{array}{c}14.3(5.7) \\
13.1(3.5 \text { to } 24.0)\end{array}$ & $\begin{array}{c}9.1(5.5) \\
8.2(2.0 \text { to } 25.0)\end{array}$ & $\begin{array}{c}9.6(5.5) \\
8.8(2.0 \text { to } 25.0)\end{array}$ & $\begin{array}{c}<0.001 \\
\text { OH-TA }<0.001 \\
\text { OH-TAS }<0.001 \\
\text { OL-TA }<0.001 \\
\text { OL-TAS }<0.001\end{array}$ \\
\hline Smell & $\begin{array}{c}0.0(0.2) \\
0.0(0 \text { to } 1)\end{array}$ & $\begin{array}{c}0.1(0.3) \\
0.0(0 \text { to } 2)\end{array}$ & $\begin{array}{l}1.8(1.6) \\
1.5(0 \text { to } 5)\end{array}$ & $\begin{array}{l}1.3(1.4) \\
1.0(0 \text { to } 5)\end{array}$ & $\begin{array}{c}<0.001 \\
\text { OH-TA }<0.001 \\
\text { OH-TAS }<0.001 \\
\text { OL-TA }<0.001 \\
\text { OL-TAS }<0.001\end{array}$ \\
\hline Application comfort & $\begin{array}{c}0.0(0.0) \\
0.0(0 \text { to } 0)\end{array}$ & $\begin{array}{c}0.6(5.6) \\
0.0(0 \text { to } 50)\end{array}$ & $\begin{array}{c}6.3(14.7) \\
0.0(0 \text { to } 60)\end{array}$ & $\begin{array}{c}0.6(3.2) \\
0.0(0 \text { to } 20)\end{array}$ & $\begin{array}{c}<0.001 \\
\text { OH-TA }<0.001 \\
\text { OH-TAS } 0.078 \\
\text { OL-TA }<0.001 \\
\text { OL-TAS } 0.352\end{array}$ \\
\hline
\end{tabular}

This is consistent with the results of previous studies evaluating the outcomes obtained with different types of liposomal sprays for dry eye [10] [11]. Pult et al. [10] demonstrated in a comparative study that the use of TA improved comfort by a mean factor of 1.5 in a sample of 80 subjects and increased significantly the TBUT. In contrast, in another study McGinnigle et al. [9] failed to find significant differences in subjective comfort using TA. In our sample, TA and TAS provided a significantly lower increase in subjective comfort compared to $\mathrm{OH}$ and OL. One of the main factors contributing to this may be differences in $\mathrm{pH}$ among the different formulations evaluated, with the best outcome in terms of 
Table 5. Changes obtained in the analyzed sample at 10 and 30 minutes after the application of each spray in subjective comfort, redness and break-up time. Abbreviations: TBUT, tear break up time; OH, Ocuvers Hyaluron; TA, Tears Again; TAS, Tears Again Sensitive; OL, Ocuvers Lipostamin.

\begin{tabular}{|c|c|c|c|c|c|}
\hline $\begin{array}{c}\text { Mean (SD) } \\
\text { Median (Range) }\end{array}$ & $\mathrm{OH}$ & OL & TA & TAS & p-value \\
\hline \multicolumn{6}{|c|}{10 Minutes after the Application of the Spray } \\
\hline Subjective comfort & $\begin{array}{c}17.2(19.2) \\
20.0(-40 \text { to } 80)\end{array}$ & $\begin{array}{c}16.2(18.8) \\
20.0(-30 \text { to } 80)\end{array}$ & $\begin{array}{c}-6.8(22.7) \\
0.0(-85 \text { to } 50)\end{array}$ & $\begin{array}{c}5.5(18.0) \\
0.0(-50 \text { to } 40)\end{array}$ & $\begin{array}{c}<0.001 \\
\text { OH-TA }<0.001 \\
\text { OH-TAS }<0.001 \\
\text { OL-TA }<0.001 \\
\text { OL-TAS }<0.001\end{array}$ \\
\hline Ocular redness & $\begin{array}{c}-0.04(0.27) \\
0.00(-1 \text { to } 1)\end{array}$ & $\begin{array}{l}-0.04(0.19) \\
0.00(-1 \text { to } 0)\end{array}$ & $\begin{array}{c}0.08(0.26) \\
0.00(0 \text { to } 1)\end{array}$ & $\begin{array}{c}0.02(0.15) \\
0.00(0 \text { to } 1)\end{array}$ & $\begin{array}{c}0.005 \\
\text { OH-TA } 0.011 \\
\text { OH-TAS } 0.095 \\
\text { OL-TA } 0.003 \\
\text { OL-TAS } 0.025\end{array}$ \\
\hline $\begin{array}{l}\text { Bulbar and nasal } \\
\text { conjunctival redness }\end{array}$ & $\begin{array}{c}-0.08(0.19) \\
-0.05(-0.60 \text { to } \\
0.50)\end{array}$ & $\begin{array}{c}-0.07(0.29) \\
-0.10(-0.90 \text { to } \\
1.99)\end{array}$ & $\begin{array}{c}0.12(0.21) \\
0.00(-0.50 \text { to } 0.70)\end{array}$ & $\begin{array}{c}0.02(0.16) \\
0.00(-0.40 \text { to } 0.90)\end{array}$ & $\begin{array}{c}<0.001 \\
\text { OH-TA }<0.001 \\
\text { OH-TAS }<0.001 \\
\text { OL-TA }<0.001 \\
\text { OL-TAS }<0.001\end{array}$ \\
\hline $\begin{array}{c}\text { TBUT } 1^{\text {st }} \text { measurement } \\
\text { (seconds) }\end{array}$ & $\begin{array}{c}1.9(6.7) \\
1.3(-19.6 \text { to } 21.3)\end{array}$ & $\begin{array}{c}2.7(5.9) \\
2.7(-22.1 \text { to } 23.2)\end{array}$ & $\begin{array}{c}-1.0(6.1) \\
-0.1(-21.4 \text { to } 19.8)\end{array}$ & $\begin{array}{c}0.5(6.5) \\
0.6(-20.4 \text { to } 19.8)\end{array}$ & $\begin{array}{c}<0.001 \\
\text { OH-TA } 0.002 \\
\text { OH-TAS } 0.137 \\
\text { OL-TA }<0.001 \\
\text { OL-TAS } 0.008\end{array}$ \\
\hline $\begin{array}{l}\text { TBUT average } \\
\text { (seconds) }\end{array}$ & $\begin{array}{c}2.8(5.8) \\
3.1(-16.0 \text { to } 17.6)\end{array}$ & $\begin{array}{c}3.8(5.5) \\
4.2(-14.4 \text { to } 19.3)\end{array}$ & $\begin{array}{c}-1.0(6.8) \\
-1.0(-21.4 \text { to } 18.6)\end{array}$ & $\begin{array}{c}0.2(6.8) \\
0.1(-17.3 \text { to } 17.7)\end{array}$ & $\begin{array}{c}<0.001 \\
\text { OH-TA }<0.001 \\
\text { OH-TAS } 0.005 \\
\text { OL-TA }<0.001 \\
\text { OL-TAS }<0.001\end{array}$ \\
\hline \multicolumn{6}{|c|}{30 Minutes after the Application of the Spray } \\
\hline Subjective comfort & $\begin{array}{c}18.7(19.6) \\
20.0(-40 \text { to } 80)\end{array}$ & $\begin{array}{c}17.1(19.2) \\
20.0(-30 \text { to } 80)\end{array}$ & $\begin{array}{c}-4.2(21.4) \\
0.0(-50 \text { to } 70)\end{array}$ & $\begin{array}{c}5.4(17.7) \\
0.0(-50 \text { to } 40)\end{array}$ & $\begin{array}{c}<0.001 \\
\text { OH-TA }<0.001 \\
\text { OH-TAS }<0.001 \\
\text { OL-TA }<0.001 \\
\text { OL-TAS }<0.001\end{array}$ \\
\hline Ocular redness & $\begin{array}{l}-0.06(0.34) \\
0.00(-1 \text { to } 1)\end{array}$ & $\begin{array}{l}-0.09(0.29) \\
0.00(-1 \text { to } 0)\end{array}$ & $\begin{array}{c}0.11(0.35) \\
0.00(-1 \text { to } 1)\end{array}$ & $\begin{array}{c}0.04(0.19) \\
0.00(0 \text { to } 1)\end{array}$ & $\begin{array}{c}<0.001 \\
\text { OH-TA } 0.002 \\
\text { OH-TAS } 0.031 \\
\text { OL-TA }<0.001 \\
\text { OL-TAS } 0.001\end{array}$ \\
\hline $\begin{array}{l}\text { Bulbar and nasal } \\
\text { conjunctival redness }\end{array}$ & $\begin{array}{c}-0.14(0.22) \\
-0.10(-0.60 \text { to } \\
0.80)\end{array}$ & $\begin{array}{c}-0.14(0.25) \\
-0.10(-0.60 \text { to } \\
1.29)\end{array}$ & $\begin{array}{c}0.10(0.31) \\
0.00(-0.90 \text { to } 1.10)\end{array}$ & $\begin{array}{c}0.00(0.18) \\
0.00(-0.50 \text { to } 0.90)\end{array}$ & $\begin{array}{c}<0.001 \\
\text { OH-TA }<0.001 \\
\text { OH-TAS }<0.001 \\
\text { OL-TA }<0.001 \\
\text { OL-TAS }<0.001\end{array}$ \\
\hline
\end{tabular}




\begin{tabular}{|c|c|c|c|c|c|}
\hline $\begin{array}{c}\text { TBUT } 1^{\text {st }} \text { measurement } \\
\text { (seconds) }\end{array}$ & $\begin{array}{c}4.4(7.1) \\
4.2(-20.4 \text { to } 20.0)\end{array}$ & $\begin{array}{c}5.0(6.4) \\
3.6(-4.1 \text { to } 20.9)\end{array}$ & $\begin{array}{c}-0.5(6.0) \\
0.1(-18.0 \text { to } 20.3)\end{array}$ & $\begin{array}{c}0.6(5.4) \\
0.4(-15.5 \text { to } 18.2)\end{array}$ & $\begin{array}{c}<0.001 \\
\text { OH-TA }<0.001 \\
\text { OH-TAS }<0.001 \\
\text { OL-TA }<0.001 \\
\text { OL-TAS }<0.001\end{array}$ \\
\hline $\begin{array}{l}\text { TBUT average } \\
\text { (seconds) }\end{array}$ & $\begin{array}{c}4.6(6.0) \\
4.4(-16.9 \text { to } 20.0)\end{array}$ & $\begin{array}{c}5.7(6.2) \\
5.3(-10.9 \text { to } 19.8)\end{array}$ & $\begin{array}{c}-1.1(5.9) \\
-0.4(-16.1 \text { to } 18.6)\end{array}$ & $\begin{array}{c}-0.1(5.7) \\
0.0(-11.9 \text { to } 17.7)\end{array}$ & $\begin{aligned}<0.001 \\
\text { OH-TA }<0.001 \\
\text { OH-TAS }<0.001 \\
\text { OL-TA }<0.001 \\
\text { OL-TAS }<0.001\end{aligned}$ \\
\hline
\end{tabular}

Table 6. Correlations between changes in the parameters evaluated and the baseline OSDI score. Abbreviations: TBUT, tear break up time; OH, Ocuvers Hyaluron; TA, Tears Again; TAS, Tears Again Sensitive; OL, Ocuvers Lipostamin.

\begin{tabular}{|c|c|c|c|c|}
\hline Coefficient of correlation p-value & $\mathrm{OH}$ & OL & TA & TAS \\
\hline \multicolumn{5}{|l|}{ Change subjective comfort } \\
\hline \multirow[t]{2}{*}{10 minutes } & 0.328 & 0.278 & 0.236 & 0.227 \\
\hline & 0.002 & 0.013 & 0.035 & 0.037 \\
\hline \multirow[t]{2}{*}{30 minutes } & 0.356 & 0.251 & 0.285 & 0.172 \\
\hline & 0.001 & 0.025 & 0.010 & 0.114 \\
\hline \multicolumn{5}{|l|}{ Change ocular redness } \\
\hline \multirow[t]{2}{*}{10 minutes } & -0.154 & -0.287 & 0.047 & 0.103 \\
\hline & 0.158 & 0.011 & 0.676 & 0.349 \\
\hline \multirow[t]{2}{*}{30 minutes } & -0.085 & -0.237 & -0.011 & -0.009 \\
\hline & 0.441 & 0.037 & 0.921 & 0.933 \\
\hline \multicolumn{5}{|c|}{ Change bulbar and nasal conjunctival redness } \\
\hline \multirow[t]{2}{*}{10 minutes } & -0.163 & -0.119 & 0.134 & -0.132 \\
\hline & 0.133 & 0.299 & 0.236 & 0.233 \\
\hline \multirow[t]{2}{*}{30 minutes } & -0.332 & 0.002 & 0.096 & -0.086 \\
\hline & 0.002 & 0.983 & 0.402 & 0.436 \\
\hline \multicolumn{5}{|l|}{ Change TBUT $1^{\text {st }}$ measurement (seconds) } \\
\hline \multirow[t]{2}{*}{10 minutes } & 0.133 & 0.115 & 0.038 & 0.096 \\
\hline & 0.218 & 0.311 & 0.741 & 0.387 \\
\hline \multirow[t]{2}{*}{30 minutes } & 0.060 & -0.131 & 0.047 & -0.124 \\
\hline & 0.588 & 0.271 & 0.690 & 0.285 \\
\hline \multicolumn{5}{|l|}{ Change TBUT average (seconds) } \\
\hline \multirow[t]{2}{*}{10 minutes } & 0.073 & 0.165 & 0.038 & 0.193 \\
\hline & 0.503 & 0.145 & 0.741 & 0.078 \\
\hline \multirow[t]{2}{*}{30 minutes } & 0.136 & 0.044 & -0.006 & -0.045 \\
\hline & 0.216 & 0.716 & 0.957 & 0.698 \\
\hline
\end{tabular}

ocular comfort for those with $\mathrm{pH}$ closest to the physiological $\mathrm{pH}$ of tears [14]. Likewise, differences in viscosity or changes induced in tear viscosity due to the application of the spray may have also contributed to differences in ocular comfort between groups [15]. More studies about the composition and behaviour of liposomal sprays in healthy and dry eye subjects should be conducted in order to better understand the mechanism of action of liposomal sprays. The significantly higher improvement in ocular comfort with $\mathrm{OH}$ and $\mathrm{OL}$ compared to TA and 


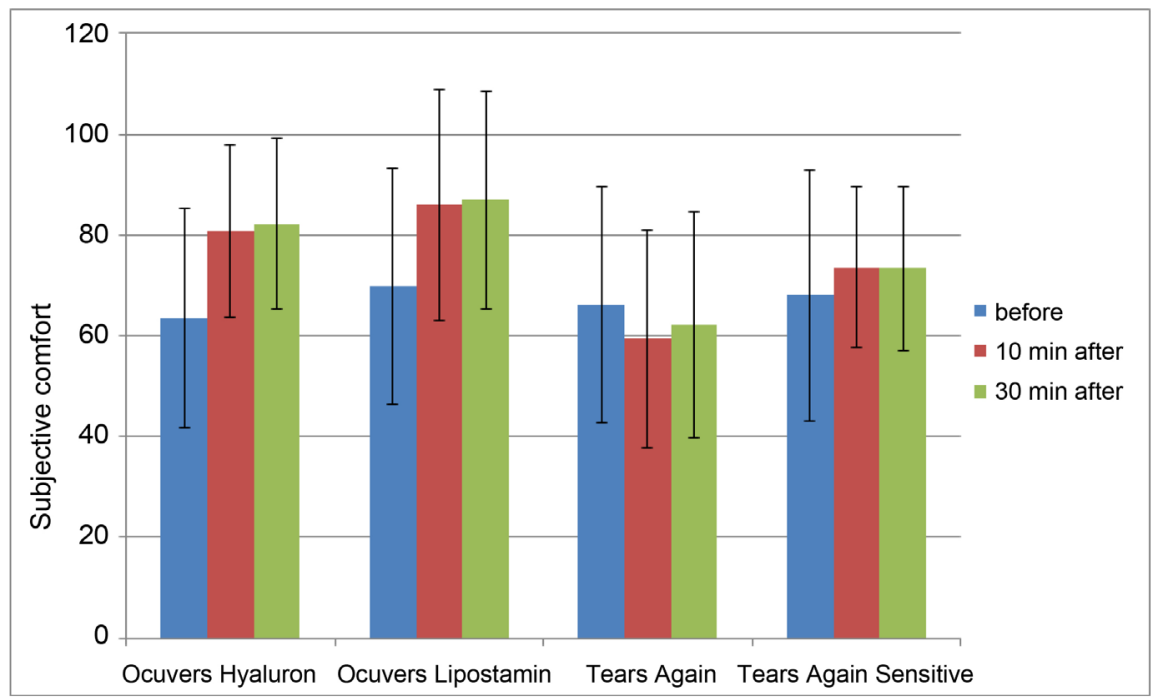

(a)

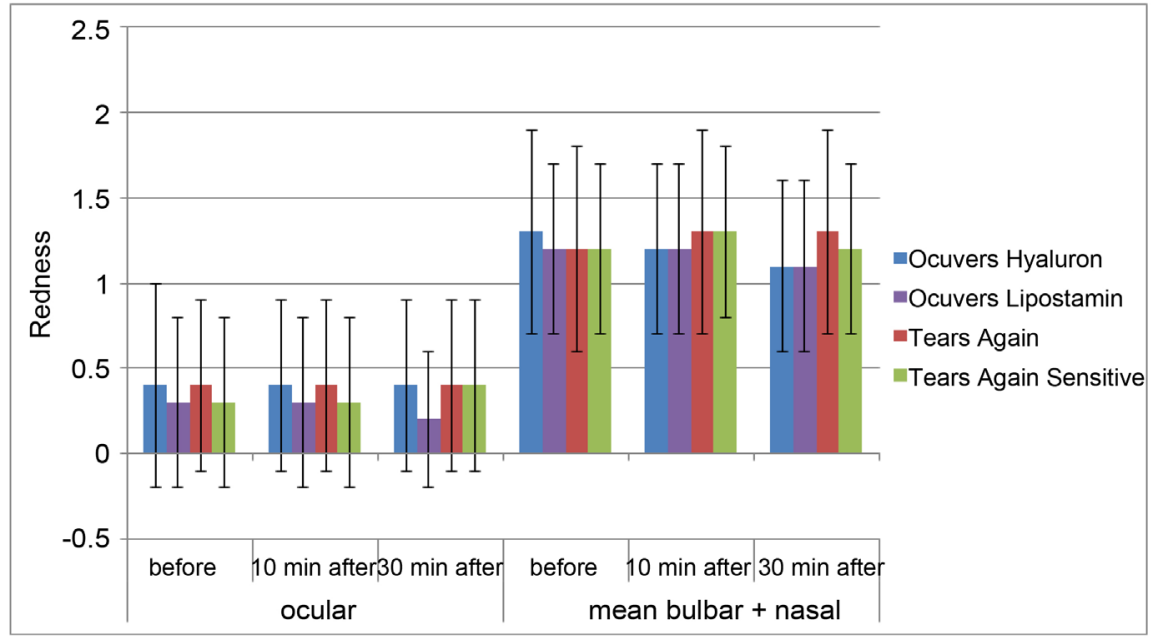

(b)

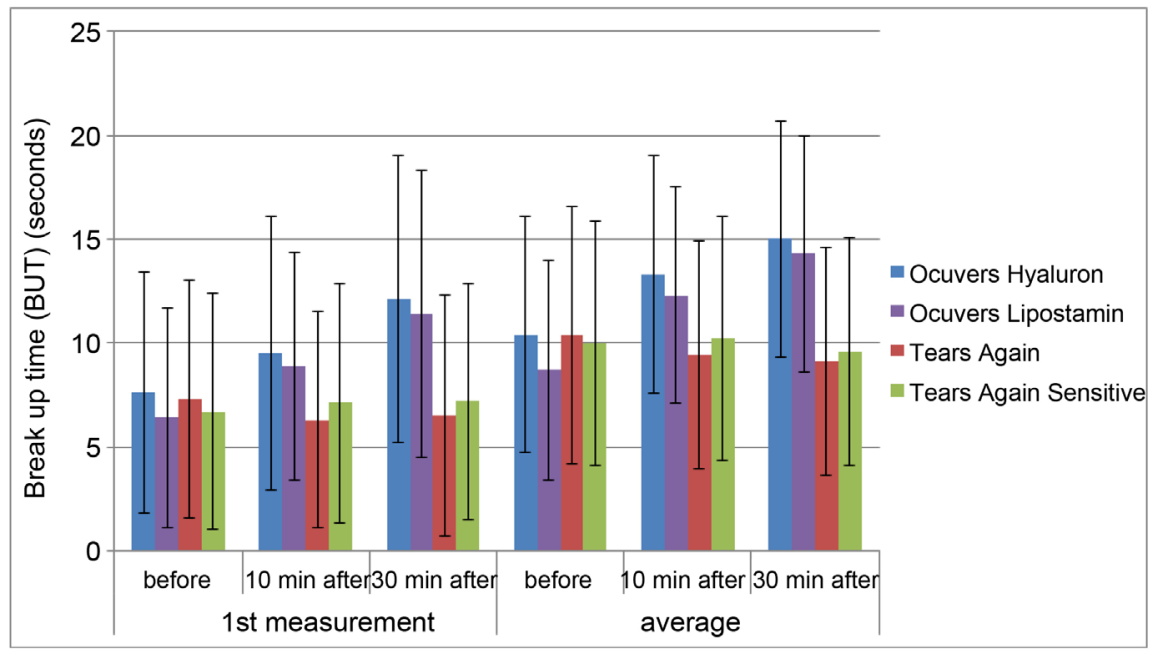

(c)

Figure 1. Distribution of subjective comfort (a) redness (b) and non-invasive tear breakup time (c) outcomes before, 10 minutes after and 30 minutes after the application of each liposome spray. 


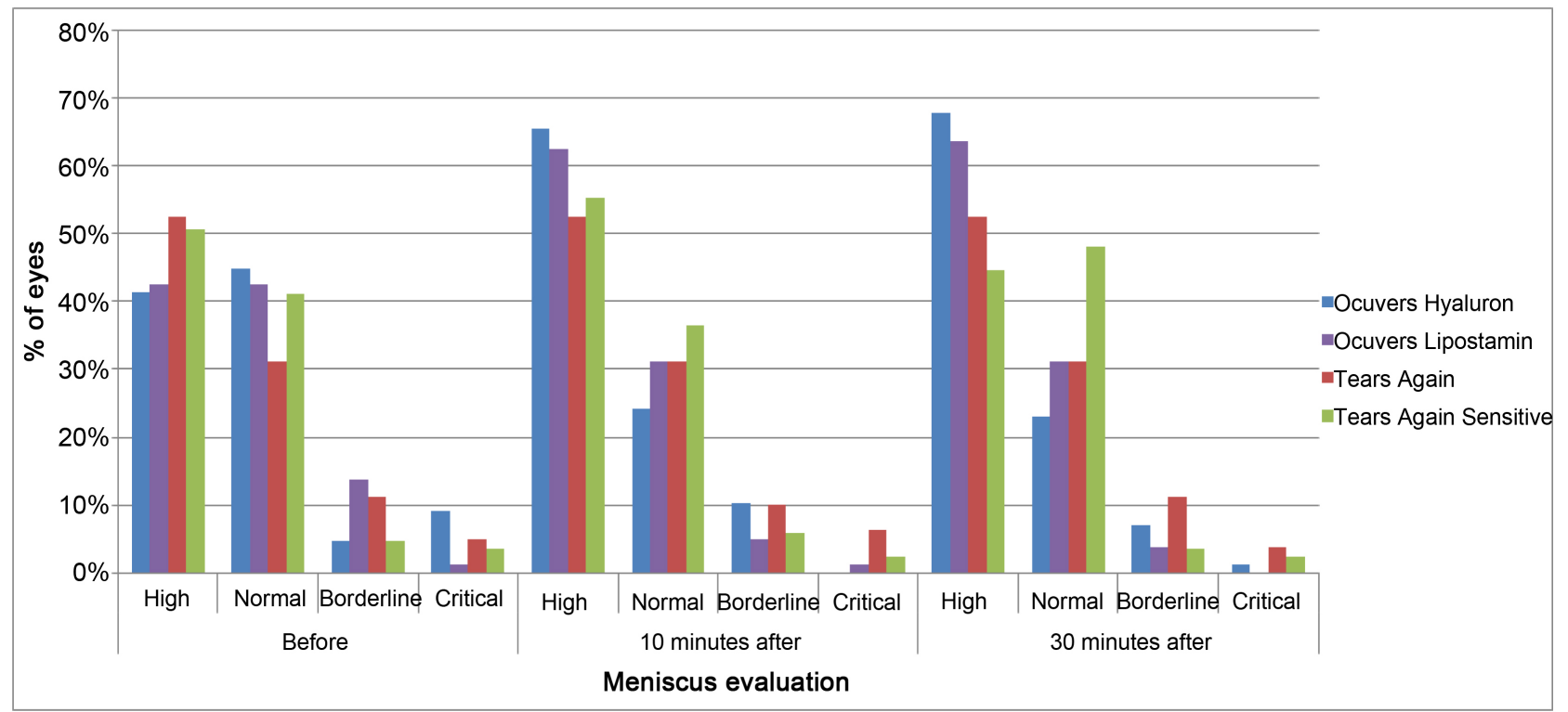

Figure 2. Distribution of the meniscus evaluation outcomes before, 10 minutes after and 30 minutes after the application of each liposome spray.

TAS found in our sample was also consistent with the more significant improvement observed in conjunctival redness, TBUT and tear meniscus. Therefore, $\mathrm{OH}$ and $\mathrm{OL}$ induced a more significant stabilization of the tear film and consequently a more stable ocular surface.

As OSDI has been demonstrated to be a valid and reliable instrument for measuring the severity of dry eye [13] the correlation between this parameter and changes occurring in different clinical parameters has been investigated to confirm, if the improvement using the evaluated liposomal sprays was better in those eyes with severe dry eye symptomatology. This correlation analysis has shown that OSDI was positively correlated only with changes in ocular comfort, except for the change in comfort at 30 minutes after the application of TAS. This confirms that the evaluated sprays induced a more significant effect on ocular comfort in those eyes with more symptoms. Although all correlations were poor, the strongest correlations were found with $\mathrm{OH}$ and OL. Furthermore, a significant negative correlation was found between the change in ocular redness and OSDI using OL. This means that more reduction of conjunctival redness was achieved in those eyes with higher OSDI or more symptomatology of dry eye. Therefore, OL seems to be the best option of the four sprays for reducing conjunctival redness in severe dry eye. The better performance in terms of ocular redness of this specific spray compared to the rest may be related to its different composition. Göbbels and Gross [16] demonstrated in a comparative study that dry eye treatment with eye drops containing dexpanthenol, a component which is present in TAS, led to a favorable and -compared to dexpanthenol-free eye drops-superior improvement of disturbances of corneal epithelium permeability. Likewise, the inclusion of plant extracts in OL may have contributed to the clinical effect observed for this spray. There are several studies confirming the 
benefit of treating dry eyes with specific plants extracts, such as improving clinical signs, decreasing inflammation, and ameliorating oxidative stress markers [17] [18] [19] [20] [21]. Possibly, the plant extracts in OL might explain the more effective reduction in conjunctival redness in eyes with severe dry eye in which a significant inflammatory process is present. This should be confirmed in future experimental research, examining the exact impact of these extracts on the ocular surface and how they affect the potential inflammatory process associated to dry eye symptoms.

Besides the evaluation of clinical outcomes, other aspects related to the four sprays have been analysed, such as comfort during application itself and smell. Significant differences between sprays have been detected in these variables, with less initial burning sensation after the application of $\mathrm{OH}$ or $\mathrm{OL}$ and the worst response with TA. This is consistent with previous studies evaluating the clinical effect of TA and reporting an initial burning sensation after the application of this spray [7]. The initial sensation with $\mathrm{OH}$ and OL was good, with minimal level of burning. Smell was significantly fattier with TA and TAS compared to $\mathrm{OH}$ and $\mathrm{OL}$. None of the $\mathrm{OH}$ and OL patients reported a strong or very strong fatty smell, in contrast to $36.5 \%$ and $57.5 \%$ of the TA and TAS patients, respectively. This seems to be related to the composition of these liposomal sprays.

\section{Conclusion}

The four liposomal sprays evaluated are useful for the treatment of dry eye symptoms, with higher improvement in subjective comfort, ocular redness, TBUT, and tear meniscus using $\mathrm{OH}$ or OL. The most prominent differences between the Ocuvers and Tears Again sprays were found for TBUT and smell with highly significant better TBUT and less fatty smell of the Ocuvers products. The use of OL seems to be more appropriate in cases of severe dry eye symptomatology, allowing a more significant reduction of ocular redness, possibly due to a more effective reduction of the associated inflammatory process. Likewise, the initial burning sensation after the application of the spray is significantly higher with the use of TA and therefore might be not recommendable in cases with severe symptoms and disturbances. As patient compliance to treatments is strongly related to subjective sensation and tolerability, the better subjective comfort, application comfort and smell of the $\mathrm{OH}$ and $\mathrm{OL}$ sprays should lead to a better adherence to treatment plans, resulting in a better clinical outcome. It seems that the latest developments in dry eye therapy, which $\mathrm{OH}$ and $\mathrm{OL}$ are based on, provide a better tolerability and efficacy compared to earlier generations of sprays.

\section{Disclosure}

No financial interest in any product mentioned in the manuscript.

\section{Conflict of Interest}

No conflict of interest. 


\section{References}

[1] DEWS Definition and Classification Subcommittee (2007) The Definition and Classi-fication of Dry Eye Disease: Report of the Definition and Classification Subcommittee of the International Dry Eye Workshop 2007. The Ocular Surface, 5, 75-92. https://doi.org/10.1016/S1542-0124(12)70081-2

[2] Schaumberg, D.A., Sullivan, D.A., Buring, J.E. and Dana, M.R. (2003) Prevalence of Dry Eye Syndrome among US Women. American Journal of Ophthalmology, 136, 318-326. https://doi.org/10.1016/S0002-9394(03)00218-6

[3] Lee, A.J., Lee, J., Saw, S.M., Gazzard, G., Koh, D., Widjaja, D. and Tan, D.T. (2002) Prevalence and Risk Factors Associated with Dry Eye Symptoms: A Population Based Study in Indonesia. British Journal of Ophthalmology, 86, 1347-1351. https://doi.org/10.1136/bjo.86.12.1347

[4] Yazdani, C., McLaughlin, T., Smeeding, J.E. and Walt, J. (2001) Prevalence of Treated Dry Eye Disease in a Managed Care Population. Clinical Therapeutics, 23, 1672-1682. https://doi.org/10.1016/S0149-2918(01)80136-3

[5] Moss, S.E., Klein, R. and Klein, B.E. (2000) Prevalence of and Risk Factors for Dry Eye Syndrome. Archives of Ophthalmology, 118, 1264-1268.

[6] Al-Saedi, Z., Zimmerman, A., Bachu, R.D., Dey, S., Shah, Z., Baugh, R. and Boddu, S.H. (2016) Dry Eye Disease: Present Challenges in the Management and Future Trends. Current Pharmaceutical Design, 22, 4470-4490. https://doi.org/10.2174/1381612822666160614012634

[7] Lee, S., Dausch, S., Maierhofer, G. and Dausch, D. (2004) [A New Therapy Concept for the Treatment of Dry Eye-The Usefulness of Phospholipid Liposomes]. Klinische Monatsblatter fur Augenheilkunde, 221, 825-836.

https://doi.org/10.1055/s-2004-813715

[8] Rohit, A., Willcox, M.D., Brown, S.H., Mitchell, T.W. and Stapleton, F. (2014) Clinical and Biochemical Tear Lipid Parameters in Contact Lens Wearers. Optometry and Vision Science, 91, 1384-1390.

[9] McGinnigle, S., Eperjesi, F. and Naroo, S.A. (2014) A Preliminary Investigation into the Effects of Ocular Lubricants on Higher Order Aberrations in Normal and Dry Eye Subjects. Contact Lens \& Anterior Eye, 37, 106-110. https://doi.org/10.1016/j.clae.2013.08.156

[10] Pult, H., Gill, F. and Riede-Pult, B.H. (2012) Effect of Three Different Liposomal Eye Sprays on Ocular Comfort and Tear Film. Contact Lens \& Anterior Eye, 35, 203-207. https://doi.org/10.1016/j.clae.2012.05.003

[11] Craig, J.P., Purslow, C., Murphy, P.J. and Wolffsohn, J.S. (2010) Effect of a Liposomal Spray on the Pre-Ocular Tear Film. Contact Lens \& Anterior Eye, 33, 83-87. https://doi.org/10.1016/j.clae.2009.12.007

[12] Dausch, D., Lee, S., Dausch, D., Kim, J.C., Schwert, G. and Michelson, W. (2006) [Comparative Study of Treatment of the Dry Eye Syndrome Due to Disturbances of the Tear Film Lipid Layer with Lipid-Containing Tear Substitutes]. Klinische Monatsblatter fur Augenheilkunde, 223, 974-983. https://doi.org/10.1055/s-2006-927266

[13] Schiffman, R.M., Christianson, M.D., Jacobsen, G., Hirsch, J.D. and Reis, B.L. (2000) Reliability and Validity of the Ocular Surface Disease Index. Archives of Ophthalmology, 118, 615-621. https://doi.org/10.1001/archopht.118.5.615

[14] López-Alemany, A., Montés-Micó, R. and García-Valldecabres, M. (1999) Ocular Physiology and Artificial tears. Journal of the American Optometric Association, 70, 455-450. 
[15] Simmons, P.A. and Vehige, J.G. (2007) Clinical Performance of a Mid-Viscosity Artificial Tear for Dry Eye Treatment. Cornea, 26, 294-302.

[16] Göbbels, M. and Gross, D. (1996) [Clinical Study of the Effectiveness of a Dexpanthenol Containing Artificial Tears Solution (Siccaprotect) in Treatment of Dry Eyes]. Klinische Monatsblatter fur Augenheilkunde, 209, 84-88.

[17] Choi, W., Lee, J.B., Cui, L., Li, Y., Li, Z., Choi, J.S., Lee, H.S. and Yoon, K.C. (2016) Therapeutic Efficacy of Topically Applied Antioxidant Medicinal Plant Extracts in a Mouse Model of Experimental Dry Eye. Oxidative Medicine and Cellular Longevity, 2016, Article ID: 4727415. https://doi.org/10.1155/2016/4727415

[18] Kim, K.A., Hyun, L.C., Jung, S.H. and Yang, S.J. (2016) The Leaves of Diospyros kaki Exert Beneficial Effects on a Benzalkonium Chloride-Induced Murine Dry Eye Model. Molecular Vision, 22, 284-293.

[19] Li, J., Deng, R., Hua, X., Zhang, L., Lu, F., Coursey, T.G., Pflugfelder, S.C. and Li, D.Q. (2016) Blueberry Component Pterostilbene Protects Corneal Epithelial Cells from Inflammation via Anti-Oxidative Pathway. Scientific Reports, 6, Article No. 19408.

[20] Choi, W., Kim, J.C., Kim, W.S., Oh, H.J., Yang, J.M., Lee, J.B. and Yoon, K.C. (2015) Clinical Effect of Antioxidant Glasses Containing Extracts of Medicinal Plants in Patients with Dry Eye Disease: A Multi-Center, Prospective, Randomized, Double-Blind, Placebo-Controlled Trial. PLoS ONE, 10, e0139761. https://doi.org/10.1371/journal.pone.0139761

[21] Hitoe, S., Tanaka, J. and Shimoda, H. (2014) MaquiBright ${ }^{\mathrm{Tm}}$ Standardized Maqui Berry Extract Significantly Increases Tear Fluid Production and Ameliorates Dry EyeRelated Symptoms in a Clinical Pilot Trial. Panminerva Medica, 56, 1-6.

Submit or recommend next manuscript to SCIRP and we will provide best service for you:

Accepting pre-submission inquiries through Email, Facebook, LinkedIn, Twitter, etc. A wide selection of journals (inclusive of 9 subjects, more than 200 journals)

Providing 24-hour high-quality service

User-friendly online submission system

Fair and swift peer-review system

Efficient typesetting and proofreading procedure

Display of the result of downloads and visits, as well as the number of cited articles

Maximum dissemination of your research work

Submit your manuscript at: http://papersubmission.scirp.org/

Or contact ojoph@scirp.org 